\title{
Cut unkind to chemistry
}

\section{London}

THE chemistry department at Royal Holloway and Bedford New College (RHBN), announcing that it will take on no new students this October, has become the latest casualty of the continuing financial crisis in British universities. Students who had already accepted places are to be offered alternative courses at RHBN or referred to other institutions. Once existing students leave, only three or four staff will remain to teach chemistry to geology and biochemistry students. Ironically, RHBN is one of five sites in the University of London earmarked for an expansion of science teaching.

Like many of London's colleges, RHBN is accumulating a financial deficit,

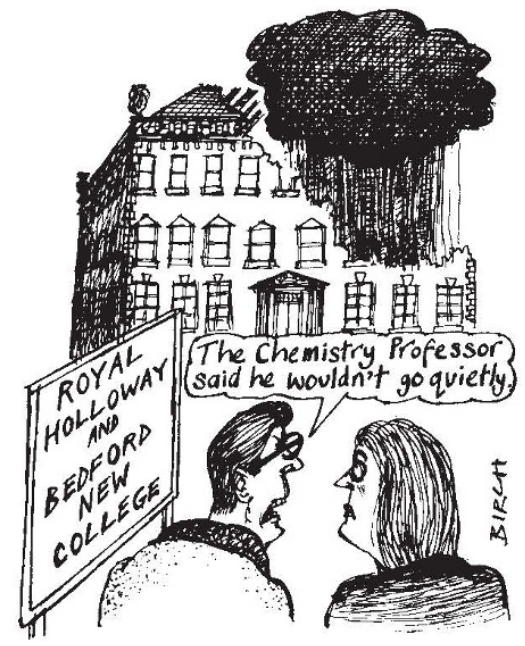

in its case at the rate of $£ 1$ million per year. It has floated several ideas to raise funds, including selling part of its art collection, and building high-quality housing on its botanical gardens.

Closing the chemistry department will make only a small dent in RHBN's deficit, but the decision was swayed by the expectation that the Universities Funding Council (UFC) will finance the necessary early retirements. If cuts were made elsewhere, RHBN principal Professor Dorothy Wedderburn says, the UFC would accept no responsibility.

The department was chosen by the UFC for restructuring following a nationwide review of university chemistry and physics departments under the UFC's predecessor, the University Grants Committee (UGC). It was concluded that departments should have more than 200 full-time undergraduate students to be viable. In general, the UFC has not forced changes upon small chemistry departments, but the University of London's senate was informed in October last year that the UFC would accept no new chemistry students at RHBN unless the department could move above the 200 -student level. Wedderburn believes the department's relatively poor research rating with the UFC influenced this action.

The chemistry and physics review was one of a series pursued by the UGC in the late $1980 \mathrm{~s}$, which resulted in several department mergers and closures. The UFC has now abandoned these reviews, and has instead introduced a competitive bidding system for student places (see Nature 342, 843; 1989). Universities must say by June next year how many students in each subject they wish to teach in 199495 , and student numbers will be allocated by the UFC from 1991-92 according to these figures.

In theory, this should mean that universities may plan their own long-term strategies, and not have rapid changes forced upon them such as those to which RHBN has succumbed. But the new system is beset by uncertainties. Continuing deficits may force some institutions, to make cuts, and the bidding system itself is far from clear.

The UFC circular letter which explained the system said that the allocation of student places would depend partly on "offer prices" made by universities for the cost of each place. But financially stretched universities are worried that they may not be able to make competitive offers, and will suffer accordingly.

Understandably, the UFC's vague assurance that it would "not expect to ask any university to face a rate of contraction of resources which it could not manage", has done little to reduce these fears.

In contrast, the bidding system introduced by the Polytechnics and Colleges Funding Council for 1990-91 funding guaranteed support at 95 per cent of the previous year's level, with competitive bidding only for the last 5 per cent.

\section{Peter Aldhous}

\section{STUDENT LOANS}

\section{Universities to take more of the strain}

\section{London}

THE British government is amending the student loans bill to compel universities to help implement the controversial scheme. This follows the refusal of university vicechancellors to cooperate any further than required by law (see Nature 344, 1; 1 March 1990).

Universities must confirm that students are eligible for a loan, but are not yet, as was feared, required to check on students' financial references. Department of Education and Science officials say they will discuss any arrangements to reimburse universities' additional administrative costs with the Committee of Vice-Chancellors at a future date.

\section{Lab's future uncertain}

\section{London}

IN a strongly worded letter to Ron Coleman, chief scientist at the UK Department of Trade and Industry (DTI), 300 staff members at the DTI's National Engineering Laboratory (NEL), in East Kilbride, Scotland, demand urgent action to define the laboratory's future. Uncertainty over the NEL's role and shedding of staff, the letter says, "are preying on us like a cancer". In common with several other government-financed laboratories, the NEL is to be reconstituted as a 'government agency', with more freedom to manage its own finances. But the NEL's case is unusual in that agency status is designed as an intermediate step towards an eventual sell-off to private investors, probably in the mid-1990s.

The government's reorganization policy is to give NEL and other laboratories an 'arm's-length' relationship with parent departments, but the letter claims that the DTI has shifted plans for the NEL "from week to week". One NEL researcher says "I'm not sure if there is a master plan", and the letter says that staff cuts threaten "whole areas of research", which include the development of renewable energy sources, alternatives to chlorofluorocarbons (CFCs) and computerized manufacturing.

Since privatization plans were first announced almost two years ago, the NEL's staff has been cut from 620 to 525 , with further reductions to about 400 planned for the near future. DTI will support the laboratory in the short term ( $£ 11$ million over the next three years, compared with about $£ 20$ million a year at present), after which the NEL must exist entirely on its research contracts. There will be no forced redundancies, according to the DTI, but the staff say that in the absence of detailed official information, "rumour runs rife". They also complain that the NEL's local management has been "emasculated" by the failure to appoint a chief executive for the new agency since the post was advertised at the beginning of the year.

The letter to DTI arose as a spontaneous action after a meeting of NEL staff, but has since been backed by the largest union at the laboratory, the Institution of Professionals, Managers and Specialists (IPMS). IPMS says the loss of staff at the NEL will jeopardize the laboratory's ability to compete for external research contracts (which account for about 20 per cent of total income). It questions the wisdom of selling a laboratory running "strategic research", such as work on energy technologies, to the private sector. 